\title{
Biokerosene Analysis from the Latex Distillation as an Alternative Solution to National Energy Crisis
}

\author{
${ }^{1}$ Tungki Pratama Umar, Muhammad Galang Samudra, Kemas Muhammad Naufal Nashor, Machlery Agung \\ Pangestu, ${ }^{2}$ Theodorus Parulian \\ ${ }^{1}$ Medical Profession Program, Faculty of Medicine, Sriwijaya University, Palembang, Indonesia, \\ ${ }^{2}$ Department of Pharmacology, Faculty of Medicine, Sriwijaya University, Palembang, Indonesia, \\ tungkipratama@gmail.com
}

\begin{abstract}
The energy crisis is ready to whack, according to the fact that about $66 \%$ of the earth's fuel comes from fossils. The urgency for alternative fuels discovery is increasing, one of such these fuels is being natural rubber latex. This material has a potential as an alternative fuel because of its high hydrocarbon content. This study was to determine rubber latex activity as biokerosene. In this study, the distillation of fresh natural rubber latex was performed and the process produces an average of $0.196 \mathrm{~L}$ of distillate per $0.5 \mathrm{~kg}$ of latex. The distillate was separated to obtain pure biokerosene. Latex biokerosene analysis shows yellow color, strong odor, nonpolar properties, flammability, yellow flame color and black smoke, $873.9 \mathrm{~kg} / \mathrm{m}^{3}$ density, $\mathrm{Rf}=0.641$ ( $4 \%$ methanol as mobile phase) and $\mathrm{Rf}=0.883$ ( $\mathrm{N}$-hexane and acetone as mobile phase) of the thin layer chromatography. It can be concluded that latex has the potential as a biokerosene and can be an alternative solution against the national energy crisis.
\end{abstract}

Keywords - Latex, Biokerosene, Energy Crisis.

\section{INTRODUCTION}

Every aspect of life requires the energy provided by fuel. Unfortunately, in many parts of the world, including Indonesia, the condition of the energy crisis is becoming a protracted issue. Based on the calculation from Indonesian Energy Outlook, Indonesia's oil reserves in 2014 is about 3.6 billion barrels and it is expected to be exhausted by 2026 [1]. That phenomenon is based on many factors such as population and economic growth [2]. The energy crisis is also related to the fact that around $66 \%$ of the world's energy consumption in 2014 comes from nonrenewable fossil fuels [3]. Attempts to overcome this energy crisis are crucial to preventing future downturns. One of the efforts exerted is to use material from nature such as latex as one kind of alternative energy that can be used as fuel to provide better productivity and decrease pollutants.

Latex potential as an alternative fuel is based on high rubber hydrocarbon content that reaches 30-40\% [4], which has not been harnessed optimally. The hydrocarbon potential of rubber latex can be an alternative solution to help prevent the energy crisis. The potential of this renewable energy is based on a relatively short harvesting preparation period compared with its quite long harvesting period (five years of preparation and up to 35 years of harvesting period, though Food and Agriculture Organization recommended that the harvesting period be up to 28 years) [5], [6]. In addition to its long harvesting period, rubber latex tapping can be done very frequently, ranging from twice a day to every four days depending on the season, soil (geographic area), and tree age [7].

South Sumatera Province, especially Banyuasin Regency, is one of the largest rubber-producing areas in Indonesia, evidenced by the statistics in 2015 from the South Sumatra Forestry Department that shows the rubber (Hevea braziliensis) farms in Banyuasin Regency covering 248,501.86 hectares (ha) with rubber production reaching 239,707.79 tons [8]. Based on these data, every hectare of rubber farms can produce about 1 ton/ha latex. In Indonesia, this number is ranging from $892 \mathrm{~kg} / \mathrm{ha}$ to $1.542 \mathrm{~kg} / \mathrm{ha}$ annually [9]. This ratio shows a relatively high prospect in rubber production.

In the meantime, the use of rubber is limited to tire production. It is a very huge problem especially with the phenomenon of scrap rubber tire generation which is exceeding 800 million pieces annually [10].

The recycling process is not going as expected and we 
must search for a new way of utilizing rubber latex to optimize community activities. One of the ways that can be adopted is to develop latex biokerosene as a renewable fuel. The researchers in this study are analyzing latex biokerosene and its value as an alternative energy source.

\section{METHODS AND MATERIALS}

The research method is based on laboratory experiments. The study took four months and was carried out at the Biomolecular Laboratory of the Faculty of Medicine, Sriwijaya University, and the Sriwijaya State Polytechnic Chemical Laboratory.

\section{Chemicals and Materials}

In the process of making the biokerosene, the researchers used $2.5 \mathrm{~kg}$ of latex (rubber sap) from rubber farm in Banyuasin, South Sumatera as the main component, standard kerosene $\left(\right.$ Pertamina $^{\circledR}$ ) as comparison substance, 6 liters of Paraffin (SigmaAldrich $^{\circledR}$ ) and distilled water (Sigma-Aldrich ${ }^{\circledR}$ ) in the distillation process, methanol $(99.8 \%$, SigmaAldrich $\left.{ }^{\circledR}\right)$, N-hexane $\left(98.5 \%\right.$, Sigma-Aldrich $\left.{ }^{\circledR}\right)$, acetone $\left(99.8 \%\right.$, Merck $\left.{ }^{\circledR}\right)$, silica gel thin-layer plate (TLC Silica gel $\left.60 \mathrm{G} \mathrm{F254,} \mathrm{Merck}^{\circledR}\right)$ for the thin layer chromatography, cut into $5 \mathrm{~cm}$ (height) $\times 2 \mathrm{~cm}$ (width) [11], and aluminum foil (Sigma-Aldrich ${ }^{\circledR}$ ).

\section{Tools}

There are some tools used in this research including distillation apparatus, oil bath, temperature regulator, thermometer, stative and clamps, Erlenmeyer flask 250 $\mathrm{mL}\left(\right.$ Pyrex $\left.{ }^{\circledR}\right)$, separator funnel, measuring cylinder in the distillation procedure, pycnometer for the density analysis, glass beaker $\left(\right.$ Pyre $\left.^{\circledR}\right)$, dropping pipette $\left(\right.$ Pyre $\left.{ }^{\circledR}\right)$, capillary pipette $\left(\right.$ Pyrex $\left.^{\circledR}\right)$ for thin-layer Chromatography(TLC), ruler and Ultraviolet (UV) reader $\left(\right.$ Eppendorf $\left.{ }^{\circledR}\right)$ for the determination of retardation factor $(\mathrm{Rf})$.

\section{RESEARCH PROCEDURE}

\section{Biokerosene production}

The procedure of biokerosene production from latex is as follows: (1) put $0.5 \mathrm{~kg}$ of latex into the distillation flask, make five experimental samples, (2) set the distillation apparatus and the temperature regulator, (3) put the distillation flask on the oil bath and fill the oil bath with $3 \mathrm{~L}$ paraffin, (4) put Erlenmeyer flask (250
$\mathrm{mL}$ ) at the end of the distillation apparatus, (5) heat the distillation flask containing the latex to $130^{\circ} \mathrm{C},(6)$ dispose of the initial distillation product (water), increase the temperature to $150-165^{\circ} \mathrm{C}[12]$ and the later distillation product as the result of the distilled latex is stored in the form of kerosene (but is still mixed with water), (7) finally, separate the oil and water with separator funnel [13]. The distillation process was done for three hours for 500 grams of raw material and stopped when there is no distillate produced in the distillation apparatus.

\section{Analysis}

Analysis for the biokerosene was done using physical examination (volume, color, smell, combustion capability, the color of the flame and smoke color), relative density measurement using a pycnometer at a temperature of $18^{\circ} \mathrm{C}$ and $28.8^{\circ} \mathrm{C}$ and thin layer chromatography test for the determination of retardation factor (Rf). The retardation factor in planar chromatography which is used in this research is defined as the ratio of the distance traveled from the center of the spot to the distance simultaneously traveled by the mobile phase as compared with the solvent [14]. Thin-layer chromatography was analyzed by using Ultraviolet (UV) reader at $254 \mathrm{~nm}$ wavelength [15]. Research procedures are simplified in figure 1.

\section{RESULTS}

\section{Distillation Products Volume}

From five distillation experiments, the average results were 0.196 liters per $0.5 \mathrm{~kg}$ of latex or about $2.55 \mathrm{~kg}$ of latex to obtain 1 liter of distillate. It is comparable with $39.2 \%$ of oil-yield (ratio of distillate per raw material dry weight). The results of distillation products can be seen in table 1.

Table 1. Data of Latex Distillation Product.

\begin{tabular}{|c|c|c|}
\hline Distillation process & Latex mass & Distillates \\
\hline 1 & $0.5 \mathrm{~kg}$ & $0.190 \mathrm{~L}$ \\
\hline 2 & $0.5 \mathrm{~kg}$ & $0.180 \mathrm{~L}$ \\
\hline 3 & $0.5 \mathrm{~kg}$ & $0.195 \mathrm{~L}$ \\
\hline 4 & $0.5 \mathrm{~kg}$ & $0.205 \mathrm{~L}$ \\
\hline 5 & $0.5 \mathrm{~kg}$ & $0.210 \mathrm{~L}$ \\
\hline Average & $0.5 \mathrm{~kg}$ & $0.196 \mathrm{~L}$ \\
\hline
\end{tabular}

\section{Macroscopic Examination}

The distillate is observed macroscopically and then 
compared with Pertamina (Perusahaan Pertambangan Minyak dan Gas Bumi Negara) kerosene. The researchers examined the oil color, smell, insolubility in water, combustion capability, the color of the flame, and its smoke. The macroscopic analysis showed that the produced biokerosene has relatively the same physical characteristics except for its smell and smoke color. The complete results are depicted in table 2.

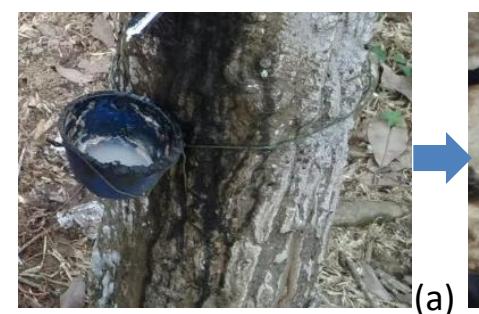

(a)

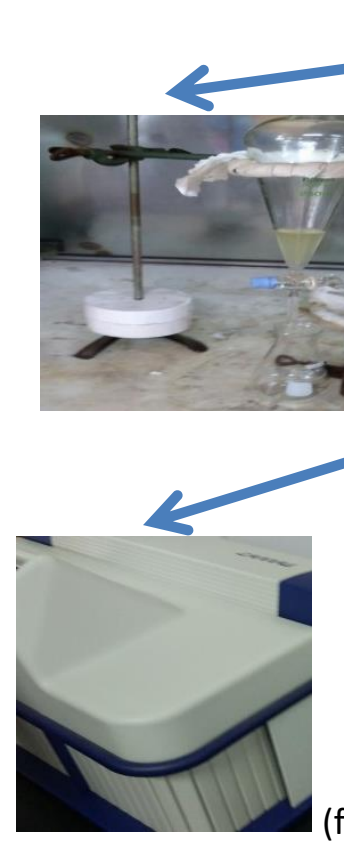

(f)

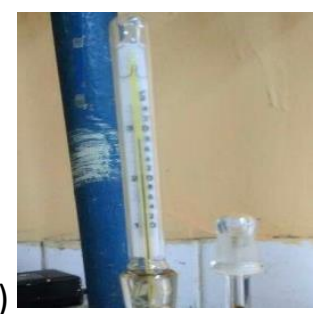

(g)

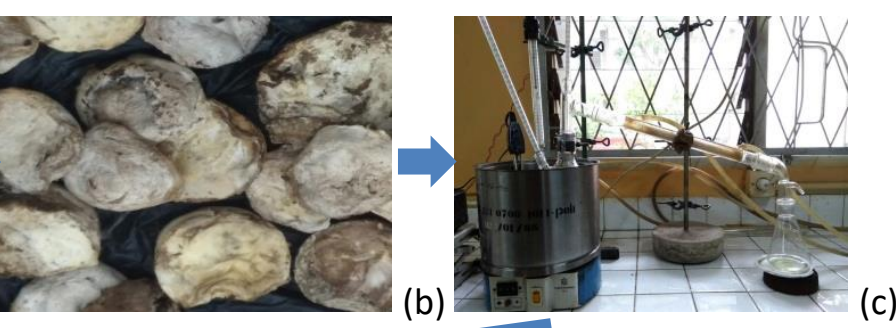

(d)

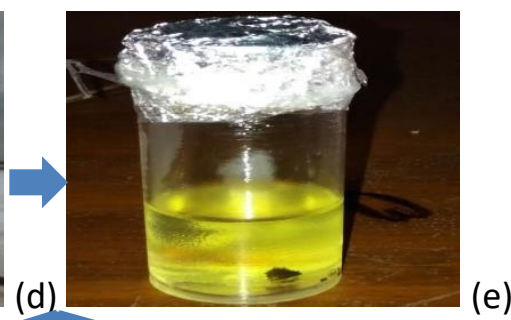

Fig. 1. Research procedure. (a) Rubber sap gathering, (b) latex dried for one week to reduce its water content,

(c) distillation procedure, (d) water and oil separation using separatory funnel, (e) latex biokerosene, then followed with outcome measurement (f) TLC analysis using UV reader, $(g)$ density measurement, (h) combustion capability measurement.

Table 2. Macroscopic Properties Comparison between Latex Biokerosene and Pertamina.

\begin{tabular}{|c|c|c|}
\hline Parameter & Latex Biokerosene & $\begin{array}{c}\text { Pertamina } \\
\text { Kerosene }\end{array}$ \\
\hline Oil color & Yellow & Yellow \\
\hline Smell & Stinky $(++)$ & Stinky $(+)$ \\
\hline Insolubility in water & Negative & Negative \\
\hline Combustion capability & Flammable & Flammable \\
\hline The color of the flame & Yellow & Yellow \\
\hline Smoke color & Black $(++)$ & Black $(+)$ \\
\hline
\end{tabular}

3. Density Measurement

The experimental procedure was examining biokerosene density at two different temperatures, $18^{\circ} \mathrm{C}$ and $28.8^{\circ} \mathrm{C}$ as the room temperature. There was no density difference between the two temperatures with $873,9 \mathrm{~g} / \mathrm{cm}^{3}$ value.

\section{Thin Layer Chromatography}

The distillate was then analyzed using thin-layer chromatography. Thin-layer chromatography is performed by using two solvent (mobile phase/eluent), $4 \%$ methanol, and the mixture of $n$ hexane and acetone at 8:2 ratio. The average $\mathrm{Rf}$ value for the produced biokerosene was slightly different with a smaller number for methanol solvent (0.641 vs. 0.696) and higher for $n$-hexane and acetone $(0.883$ vs. 0.815$)$. The full result of the retardation factor calculation is shown in table 3 . The thin layer chromatography result is shown in figure 2 . 


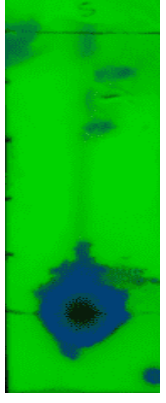

(1.a)

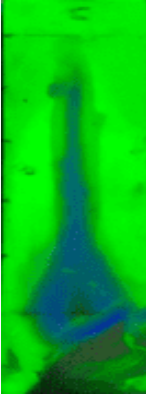

(1.b)

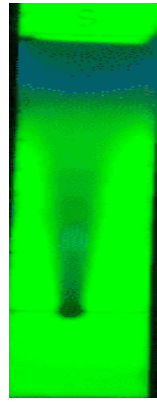

(2.a)

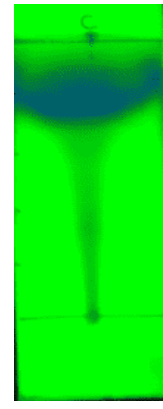

(2.b)
Fig .2 Results of thin layer chromatography. (1.a) Latex biokerosene-methanol, (1.b) Kerosene-methanol; (2.a) Latex biokerosene-hexane \& acetone (2.b) Kerosene-hexane \& acetone.

Table 2. Retardation Factor (Rf) for Latex Biokerosene and Pertamina Kerosene.

\begin{tabular}{|c|c|c|c|c|}
\hline No & $\begin{array}{c}\mathrm{Rf} \\
\text { Sample 1 }\end{array}$ & $\begin{array}{c}\mathrm{Rf} \\
\text { Standard 1 }\end{array}$ & $\begin{array}{c}\mathrm{Rf} \\
\text { Sample 2 }\end{array}$ & $\begin{array}{c}\mathrm{Rf} \\
\text { Standard 2 }\end{array}$ \\
\hline 1 & 0.600 & 0.700 & 0.900 & 0.800 \\
\hline 2 & 0.580 & 0.750 & 0.890 & 0.850 \\
\hline 3 & 0.625 & 0.680 & 0.843 & 0.833 \\
\hline 4 & 0.650 & 0.675 & 0.910 & 0.790 \\
\hline 5 & 0.750 & 0.675 & 0.870 & 0.800 \\
\hline Average & 0.641 & 0.696 & 0.883 & 0.815 \\
\hline
\end{tabular}

Note: 1 = using methanol $4 \%$ as mobile phase, $2=$ using $\mathrm{N}$ hexane + acetone (8:2) as mobile phase

\section{Utilization Testing}

A biokerosene utilization test was done by boiling 100 $\mathrm{mL}$ of water. Then it was compared to Pertamina $\AA$ kerosene. Boiling time using biokerosene is five minutes with $2,5 \mathrm{~mL}$ of biokerosene as fuel. It is $25 \%$ slower than boiling time using Pertamina kerosene (four minutes) with the same amount of fuel. This was examined by using a standard oil stove.

\section{DISCUSSION}

Based on the measurement of pure rubber latex distillation results, no significant difference is found in every distillation process. The maximum difference per experiment is 0.03 liters. The result of distillation ranged from 0.18 liters to 0.21 liters. As stated above, the produced biokerosene return oil yields about $39.2 \%$. Biokerosene from waste cooking oil distillate has a $20 \%$ oil yield [16]. Meanwhile, the analysis of rubber seed showed the highest yield of $32,4 \%$ [17].

On the macroscopic examination, it is found that distillate color is clear yellow and visually similar to kerosene. The combustion capability shown by the lamplight test is also quite good as compared to kerosene. This is due to the considerably high hydrocarbon content, which is about $30-40 \%$ [4]. The combustion process results in sufficient black smoke due to its main hydrocarbon content which is in the form of cis-1.4-polyisoprene [18]. Meanwhile, the color of the yellow flame that appears is similar to kerosene.

The distillates show practically insoluble properties in the water, like nonpolar compounds, such as kerosene. Latex biokerosene odor is quite foulsmelling because of the existence of several compounds, like low molecular weight fatty acids such as acetic acid, butyric and isovaleric acids; long-chain fatty acids such as stearic acid and aromatic compounds such as p-xylene and phenol as well as unexpected compounds such as isoamyl alcohol, benzyl alcohol, benzaldehyde, benzoic acid and phenolic acids [19].

From density measurement, the kerosene density obtained is about $873,9 \mathrm{~kg} / \mathrm{m} 3$, slightly higher than Pertamina kerosene density which has a maximum value of $835 \mathrm{~kg} / \mathrm{m} 3$ [20]. This density value is still in the range of kerosene density reference value according to the U.S. Department of Health and Human Services, where kerosene is known as number 1 fuel with density between 810-936 g/cm3 [21]. Past research on Jatropha curcas biokerosene in Nigeria showed a very small difference in density with the product ( $\rho=874.7 \mathrm{~kg} / \mathrm{m} 3)$ [22] of this research. The higher density values are due to the existence of contaminants that need to be separated furtherly. Researchers also compared the density of latex biokerosene with other fluid as shown in graph 1 [9],[10].

Graph 1. Latex biokerosene and other fuel density comparison (in $\left.\mathrm{kg} / \mathrm{m}^{3}\right)$.

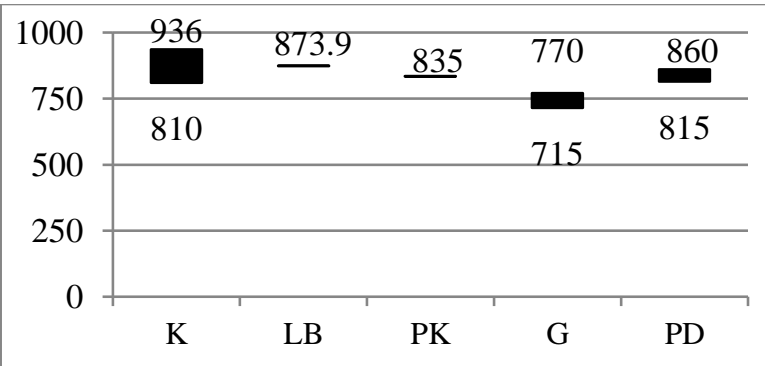

$\mathrm{K}=$ Kerosene, $\mathrm{LB}=$ Latex iokerosene, $\mathrm{PK}=$ Pertamina $^{\circledR}$ Kerosene, $\mathrm{G}=$ Pertamina $^{\circledR}$ Gasoline, PD = Pertamina ${ }^{\circledR}$ Diesel. Data comparison [9],[10].

The analysis of thin-layer chromatography was done by using a UV reader at $254 \mathrm{~nm}$ wavelength to read and calculate the retardation factor (Rf). The first experiment is done by using $4 \%$ methanol as the 
mobile phase and shows an average value of 0.641 , on the other hand, Pertamina kerosene control has an average Rf of 0.696 . Based on the data from Ko et. al., the biokerosene reaches a value of 0.641 by using $4 \%$ methanol as a mobile phase is included in the kerosene $\mathrm{Rf}$ range, i.e. 0.6-0.7 [11]. In this experiment, there are two readings, which can be concluded as the result of impure latex biokerosene. The second experiment was done by using a mixture of $n$-hexane: acetone (8:2) as a mobile phase and resulting in an average $\mathrm{Rf}$ value of 0.883 for latex biokerosene, besides Pertamina kerosene control has a mean $\mathrm{Rf}$ value of 0.815 . The results of the sample test showed that there are movements of fluid on the silica paper due to the mobile phase and the stationary phase interaction. However, based on Ramteke et. al., biokerosene Rf value of 0.883 is more than expected, which is 0.8 [23] because the distillate is not pure and still has some contaminants. The semi-quantitative method above shows that the distillate may contain biokerosene, although it needs to be purified further. Future research also must assess the functionality of this biokerosene product.

Latex biokerosene utilization was assessed by boiling water in the standard oil stove. It was proved that latex biokerosene has a $25 \%$ slower time to boil the water as compared with standard kerosene (Pertamina®) and can, therefore be used for household activity although it needs more improvement. The researchers did not find a suitable comparison for the utilization test. On the other hand, we found a burning test for efficiency testing of biokerosene from used frying palm oil as compared with standard kerosene ( $110 \mathrm{~mL} /$ minute vs. $92 \mathrm{~mL} /$ minute). It is concluded that standard kerosene is still better in efficiency considering the potential of biokerosene from used frying oil [24].

In the future, biokerosene implementation should be on a larger scale to fulfill national needs or even worldwide use. When we are talking about latex production especially in Indonesia, it is estimated that 3.229.861 tons of rubber latex generated yearly [25]. Based on these data, latex biokerosene, if effectively produced, can reach more than 1.2 billion liters or about 7.8 million barrels annually. It is exceeding kerosene demand in Indonesia by 2014 which is 4.620 .000 barrel [1] and it can be concluded that latex biokerosene can be used as an alternative for facing a national energy crisis.

The produced biokerosene is still far from large scale production due to its basic method and high cost related to its production process. We need to implement some strategies before such biokerosene can be produced on a large (mass) scale. It includes enlarging biomass resource basis, providing better agricultural technology and biomass production, a greater combination of biomass production and its marketing, in addition to maximizing assessment of sustainability criteria throughout the overall provision chain [26].

\section{CONCLUSION}

Biokerosene from latex distillation has relatively similar characteristics as standard kerosene and therefore has the potential to be used as an alternative source of energy. According to scarcity of Pertamina kerosene in Indonesia, biokerosene production can be optimized as a newer option although in the meantime calculation of its production cost is still high due to the small scale production.

\section{ACKNOWLEDGEMENT}

The researcher would like to thank the Ministry of Research, Technology and Higher Education of the Republic of Indonesia for the funding of this study as well as Silvalena and Fikram Ahmad Fauzan as language reviewers. We are also grateful for Yuni Paradita Djunaidi's advice for this research

\section{REFERENCES}

[1] Badan Pengkajian dan Penerapan Teknologi. "Outlook energi Indonesia 2016: Pengembangan energi untuk mendukung Industri Hijau," Pusat Teknologi Sumberdaya Energi dan Industri Kimia Badan Pengkajian dan Penerapan Teknologi, Jakarta, 2016.

[2] J. Meliala. "Upaya optimalisasi penghematan subsidi bahan bakar minyak (BBM) agar tepat sasaran," Binus Bus. Rev., vol. 5, no. 1, pp. 333-343, 2014.

[3] International Energy Agency. "Key world energy statistics 2016," International Energy Agency, Paris, 2016, p. 6.

[4] T. Jayanthy and P. E. Sankaranarayanan. "Measurement of dry rubber content in latex using microwave technique," Meas. Sci. Rev., 
vol. 5, no. 3, pp. 50-54, 2005.

[5] S. Damanik, M. Syakir, M. Tasma, and S. Siswanto. "Budidaya dan Pasca Panen Karet," Pusat Penelitian dan Pengembangan Perkebunan, Jakarta, 2010.

[6] Food and Agriculture Organization, "The rubber tree," [Online]. Available: http://www.fao.org/3/ad221e/ad221e06.htm. [June, 7, 2020].

[7] S. Subandi. "Budidaya Tanaman Perkebunan (Bagian Tanaman Karet)," Gunung Djati Press, Bandung, 2018.

[8] Dinas Kehutanan Provinsi Sumatera Selatan, "Potensi," 2015. [Online]. Available: http://www.dishutsumsel.go.id/ 2015/09/17/potensi/. [May, 10, 2020].

[9] I. Boerhendhy and K. Amypalupy. "Optimalisasi produktivitas karet melalui penggunaan bahan tanam, pemeliharaan, sistem eksploitasi, dan peremajaan tanaman," J. Litbang Pertan., vol. 30, no. 1, pp. 23-30, 2010.

[10] H.H. Tsang. "Uses of scrap rubber tires," in Rubber: Types, Properties and Uses, G. A. Popa,Ed.. Nova Science Publishers, New York, pp. 1-15, 2010.

[11] M. S. Ko, D. Kwon, J. S. Yang, M. J. Kwon, S. W. Lee, and S. Lee. "Identifying type of refined petroleum products in environmental media: Thin layer chromatography (TLC) as a quick methodology," Water Air Soil Pollut, vol. 225, pp. 2149, 2014.

[12] N. S. Ekaab, N. H. Hamza, and M. T.Chaichan. "Performance and emitted pollutants assessment of diesel engine fuelled with biokerosene," Case Stud. Therm. Eng., vol. 13, pp. 100381, 2019.

[13] I. Syauqiah, A. Mirwan, A. Sulaiman, and D. Nurandini. "Analisis pengaruh lama penyulingan dan komposisi bahan baku terhadap rendemen dan mutu minyak atsiri dari daun dan batang nilam," Info - Tek., vol. 9, no. 1, pp. 21-30, 2008.

[14] International Union of Pure and Applied Chemistry. "Compendium of chemical terminology: Gold book," International Union of Pure and Applied Chemistry, Zurich, 2014.

[15] L. Cai, "Thin layer chromatography," in Current Protocols Essential Laboratory Techniques, S. R. Gallagher and E. A. Wiley, Eds. Wiley, London, pp. 6.3.1-6.3.18, 2014.

[16] A. E. K. Salwa, A. H. Samia, M. M. H. Arief, and F. A.-A. Eslam. "Production of petroleum - Like fractions from waste cooking oil," Egypt. J. Chem., vol. 60, no. 1, pp. 147-60, 2017.

[17] D. F. Lestari. "Rubber-tree (Hevea brasiliensis) seed oil extraction by adopting traditional method in making coconut oil," Inov. dan Pengemb., vol. 2, no. 3, pp. 1-12, 2016.

[18] D. Blackley. "Polymer latices," Science and Technology, vol. 2, Types of Latices," p. 83, 1997.

[19] N Juntarachat, N. Bouvier, J.P. Lepoutre, A. Roland, J. Sainte-Beuve, F. Granet, J.M. Salmon, P. Rigou, and P. Chalier. "Identification by GC-O and GC-MS of new odorous compounds in natural rubber," J. Appl. Polym. Sci, vol. 130, pp. 1863-1872, 2013.

[20] Direktur Jenderal Minyak dan Gas Bumi. "Keputusan direktur jenderal minyak dan gas bumi nomor 17 K/72/DDJM/1999 tentang standar dan mutu (Spesifikasi) bahan Bbkar minyak jenis minyak tanah yang dipasarkan di dalam Negeri," Indonesia, 1999.

[21] U.S. Department of Health and Human Services. "Toxicological profile for fuel oils," U.S. Department of Health and Human Services, Agency for Toxic Substances and Disease Registry, Atlanta, 1995.

[22] F. Adesina, A. Gbadegesin, A. Paul, and $O$. Oyinkepreye. "Insight into possibility of producing biokerosene from jatropha curcas plant in Nigeria," Covenant J. Eng. Technol., vol. 1, no. 1, pp. 49-58, 2017.

[23] G. Ramteke, L. Revatkar, R. Phadke, and N. Chutke. "Analysis of petrol: A clarification for purity of petrol," ESR J., vol. 1, no. 1, pp. 1-8, 
2016.

[24] M. S. Syaripuddin. "Utilization of used frying oil as biokerosene fuel," Institut Teknologi Sepuluh Nopember, Surabaya, 2009.

[25] Direktorat Jenderal Perkebunan. "Statistik perkebunan Indonesia 2015-2017: Karet," Kementerian Pertanian Indonesia, Jakarta, 2017.

[26] M. Kaltschmitt. "Biofuels - on the way to sustainability?," RESD, vol. 2, no. 2, pp. 60-63, 2016. 